\author{
Jurii Bilous \\ PhD Student of the Department of Geography of Ukraine and Regional Studies \\ e-mail: bilous_jura@ukr.net, ORCID ID: https://orcid.org/0000-0001-8539-275X \\ Yuriy Fedkovych Chernivtsi National University, \\ Mykhailo Kotsiubynsky street 2, building 4, Chernivtsi, 58012, Ukraine
}

\title{
OPTIMIZATION OF THE NETWORK OF GENERAL SECONDARY EDUCATION IN- STITUTIONS IN THE CONDITIONS OF DECENTRALIZATION: GEOGRAPHICAL ASPECT
}

\begin{abstract}
Decentralization reform includes a number of other reforms, including education reform, which is one of the most important. The main results of the reform of secondary education are: the introduction of the New Ukrainian School, the change of the system of management and financing of institutions, as well as the creation of educational districts and basic schools. Optimization of the network of general secondary education institutions (GSEI) is an important element on the way to quality educational services.

When optimizing the network of GSEI, it is necessary to take into account a number of factors, among which the most important are: quality of transport routes, distance of transportation of students, number of students who will need transportation, material and technical base of institutions (availability of computer classes, gym and classrooms), staffing of the library fund, the quality of teaching staff and others.

As of September,1 2019 there were 402 educational establishments with 105483 students in Chernivtsi oblast. Currently, 14 basic educational institutions and 22 branches have been established in Chernivtsi oblast. Among the raions, the largest number of basic educational institutions have been established in Hertsa raion. No basic educational institutions have been established in Putyla and Hlyboka raions, as well as in the city of Chernivtsi. A total of 7,354 students study in basic institutions and their branches.

To test the method of optimization of the network of GSEI, we chose Kitsman raion of Chernivtsi oblast, which is optimal for the oblast and Ukraine in general on various indicators: demographic characteristics; the size of the raion; features of the transport network; the number of GSEI and students enrolled in them and others.

Currently, there are 2 basic institutions and 2 branches in Kitsman raion. After analyzing a number of indicators (level of institutions, peculiarities of the institution location, number of students who will need transportation, area of student premises, material and technical base, staffing of the library fund, qualification of pedagogical staff and quality of graduates' knowledge), we propose to optimize Kitsman raion network of GSEI, by means of establishing of 12 educational districts, 11 basic institutions and 26 branches. In most educational districts of Kitsman raion we propose to create one basic institution, only in Kitsman educational district - two, and in Shypyntsi and Luzhany educational districts not to create any basic institution at the moment.

Keywords: decentralization, united territorial communities (UTC), educational district, general secondary education institution (GSEI), basic institution, branch, quality of students'knowledge.
\end{abstract}

Юрій Білоус. ОПТИМІЗАЦЯ МЕРЕЖІ ЗАКЛАДІВ ЗАГАЛЬНОЇ СЕРЕДНЬОЇ ОСВІТИ В УМОВАХ ДЕЦЕНТРАЛІЗАЦӤ: ГЕОГРАФІЧНИЙ АСПЕКТ

В статті розглянуто сучасний стан формування мережі опорних закладів загальної середньої освіти (З3СО) Чернівецької області, а також визначено основні чинники, які необхідно враховувати при формуванні освітнього округу та створенні опорного закладу, а також запропоновано перспективну мережу опорних З3СО Кіцманського району Чернівецької області.

Сьогодні освітня галузь України знаходиться на етапі реформування. Одними з елементів здійснення реформи освіти $\epsilon$ створення освітніх округів та опорних навчальних закладів. При плануванні опорного закладу, ми пропонуємо враховувати наступні чинники: ступінь закладів освіти, особливості їх географічного розташування, кількість учнів, що потребуватимуть підвезення, площа учнівських приміщень, матеріально-технічна база, укомплектування бібліотечного фонду, кваліфікацію педагогічних працівників та якість знань випускників. Найважливішими ж чинниками, на нашу думку, є: особливості розташування закладу (адже даний показник впливає на час та відстань підвезення учнів), матеріально-технічна база (сприяє кращому засвоєнню знань) та якість знань випускників 33СО (саме знання є показником якості надання освітніх послуг).

На даний час в Чернівецькій області вже створено 14 опорних навчальних закладів та 22 філії, в яких навчається 7354 учні. Для визначення шляхів оптимізації мережі 33СО, нами було обрано Кіцманський район Чернівецької області, адже він $є$ оптимальним для області та й України загалом, за демографічними особливостями, розмірами району, особливостями транспортної мережі, кількістю З3СО та учнів, що в них навчаються, а також відсутню шкіл 3 мовами навчання національних меншин, які потребують врахування певних особливостей при створенні опорних закладів. В Кіцманському районі ми пропонуємо створити 12 освітніх округів, 11 опорних закладів та 26 філій, а також залишити 2 33СО без змін.

Ключові слова: децентралізація, об'єднані територіальні громади, освітній округ, заклад загальної середньої освіти, опорний заклад, філія, якість знань учнів.

(C) Bilous J., 2020 
Юрий БИЛоус. ОПТИМИЗАЦИЯ СЕТИ УЧРЕЖДЕНИЙ ОБЩЕГО СРЕДНЕГО ОБРАЗОВАНИЯ В УСЛОВИЯХ ДЕЦЕНТРАЛИЗАЦИИ: ГЕОГРАФИЧЕСКИЙ АСПЕКТ

В статье рассмотрено современное состояние формирования сети опорных заведений общего среднего образования (3ОСО) Черновицкой области, а также определены основные факторы, которые необходимо учитывать при формировании образовательного округа и создании опорного учреждения, а также предложено перспективную сеть опорных ЗОСО Кицманского района Черновицкой области.

Сегодня образовательная отрасль Украины находится на этапе реформирования. Одними из элементов осуществления реформы образования является создание образовательных округов и опорных учебных заведений. При планировании опорного заведения, мы предлагаем учитывать следующие факторы: степень учебных заведений, особенности их географического расположения, количество учащихся, потребуют подвоза, площадь ученических помещений, материальнотехническая база, укомплектование библиотечного фонда, квалификацию педагогических работников и качество знаний выпускников. Важнейшими же факторами, по нашему мнению, являются: особенности расположения заведения (ведь данный показатель влияет на время и расстояние подвоза учащихся), материально-техническая база (способствует лучшему усвоению знаний) и качество знаний выпускников $30 \mathrm{CO} \mathrm{(именно} \mathrm{знания} \mathrm{являются} \mathrm{показателем} \mathrm{качества} \mathrm{предоставления}$ образовательных услуг).

В настоящее время в Черновицкой области уже создано 14 опорных учебных заведений и 22 филиала, в которых учится 7354 ученика. Для определения путей оптимизации сети 3ОСО, нами был выбран Кицманский район Черновицкой области, ведь он является оптимальным для области и Украины в целом, по демографическим особенностям, размерам района, особенностям транспортной сети, количеством ЗОСО и учащихся в них, а также в нем отсутствуют школы с языками обучения национальных меньшинств, требующих учета определенных особенностей при создании опорных заведений. В Кицманском районе мы предлагаем создать 12 образовательных округов, 11 опорных заведений и 26 филиалов, а также оставить $233 \mathrm{CO}$ без изменений.

Ключевые слова: децентрализация, объединенные территориальные общины, образовательный округ, заведение общего среднего образования, опорное заведение, филиал, качество знаний учащихся.

Statement of the research problem. Currently, Ukraine is carrying out a set of actions aimed at transferring significant powers from state to local authorities, i.e. decentralization reform. Decentralization reform includes a number of other reforms: administrative and territorial organization, medical reform, education and others. Changes in the field of education are one of the most important, because the system of education at the moment does not meet the challenges of modern society. The main results of the secondary education reform are: introduction of the concept of the New Ukrainian School, change of the system of management and financing of institutions, as well as creation of educational districts and basic schools. Socio-geographical studies of the educational complex, namely regional factors, will contribute to better organization of the network of general secondary education institutions, and, accordingly, to improving the accessibility of all citizens to quality education.

Analysis of recent research and publications. The study of decentralization of education is a relatively new direction, as the reform itself began to be implemented not so long ago. In general, the works of teachers, economists and geographers are devoted to the study of the establishment and peculiarities of the functioning of basic institutions. Teachers, economists and geographers have made a significant contribution to the study of basic institutions.

The works of economists Pashkevych M.S. and Kharchenko M.O. are devoted to the generalization and development of scientific and methodological principles and the development of practical recommendations for the formation of a network of basic schools in the regions of Ukraine, taking into account their socioeconomic indicators. They also considered the issue of determining the role and problems of territorial location of secondary education institutions in Ukraine, formed a method of forming a network of basic schools based on genetic algorithms [8]. Benovska L.Ya.'s works are devoted to the study of the formation of basic schools in the conditions of local self-government reform, as well as to the determination of the educational institution's compliance with the requirements to the basic one [2].

An important contribution to the study of the territorial organization of educational institutions was made by Stetskiy V.V., who described the structure of the educational complex of Lviv region, analyzing the links between the formation and development of education [11].

Territorial features of the cultural and educational complex of Ternopil region are studied by Flinta N.I., who determined the essence of the cultural and educational complex and revealed the structure and its territorial organization, as well as identified factors influencing the formation and functioning of this complex in modern conditions [12].

Territorial organization of the educational complex is studied in the works of Zayachuk O.H., where the analysis and generalization of socio-geographical approaches to its study and the analysis of factors of its formation and functioning are made, the sociogeographical elements of the component structure of the educational complex of Chernivtsi oblast are characterized [4].

Many researches of the educational complex were carried out by Virchenko P.A., namely: the educational potential of the Kharkiv oblast was analyzed; the role and place of the education system in the sectoral structure of education of the national infrastructure at the present stage was determined; the spatio-temporal features of preschool, general secondary, out-of-school, vocational and higher levels of the education system of the region are revealed [3].

Among foreign scholars, the works of Merkushova L., Jacobson L., Rutgeiser V. and others are devoted to the study of education. The works are mainly devoted to certain aspects of the social sphere, including the educational complex.

Formulation of the goals of the article.

The purpose of the study was to provide a socio- 
geographical analysis of the territorial differentiation of the process of optimization of the network of GSEI in Chernivtsi oblast, through the formation of educational districts and the establishment of basic educational institutions. Based on the goal, the following tasks were set: to analyze the network of basic educational institutions in Chernivtsi oblast; to identify territorial differences in the establishment of basic institutions of Chernivtsi oblast; to explore the features of the establishment of basic institutions; to suggest ways to optimize the network of GSEI on the example of Kitsman raion, because this raion of Chernivtsi oblast by most indicators is average in Ukraine.

Presentation of the main research material. Chernivtsi oblast is the smallest oblast of Ukraine, which includes 417 settlements, of which 19 are urban and 398 rural.

As of January 1, 202037 united territorial communities (UTC) have been formed in Chernivtsi oblast, and one community is awaiting approval by the Cabinet of Ministers of Ukraine [6].

The largest number of UTCs was created in Hlyboka and Zastavna raions - 6 communities each, and the only raion where no UTCs have been formed so far is Kelmentsi district. The united territorial communities have significant disparities in area, number of settlements, population, population density, number of GSEI, students, etc.

The largest in area UTC of Chernivtsi oblast is Storozhynets city united territorial community -496.27 $\mathrm{km}^{2}$, also the second largest in area is Selyatyn village united territorial community $-369.08 \mathrm{~km}^{2}$, the smallest communities are Kostryzhivka village and Stavchany village united territorial community - less than $40 \mathrm{~km}^{2}$.

The largest community in terms of population is Storozhynets city united territorial community $(38,664$ people), the smallest population is observed in UstPutyla village united territorial community $(2,231$ people).

In total, as of September 1, 2019, there were 402 educational institutions in Chernivtsi oblast, the largest number of institutions is concentrated in Chernivtsi - 53, the smallest number of institutions is in Vikno UTC - 1 GSEI. 105,483 students study in GSEI of the oblast (Fig. 1) [5].

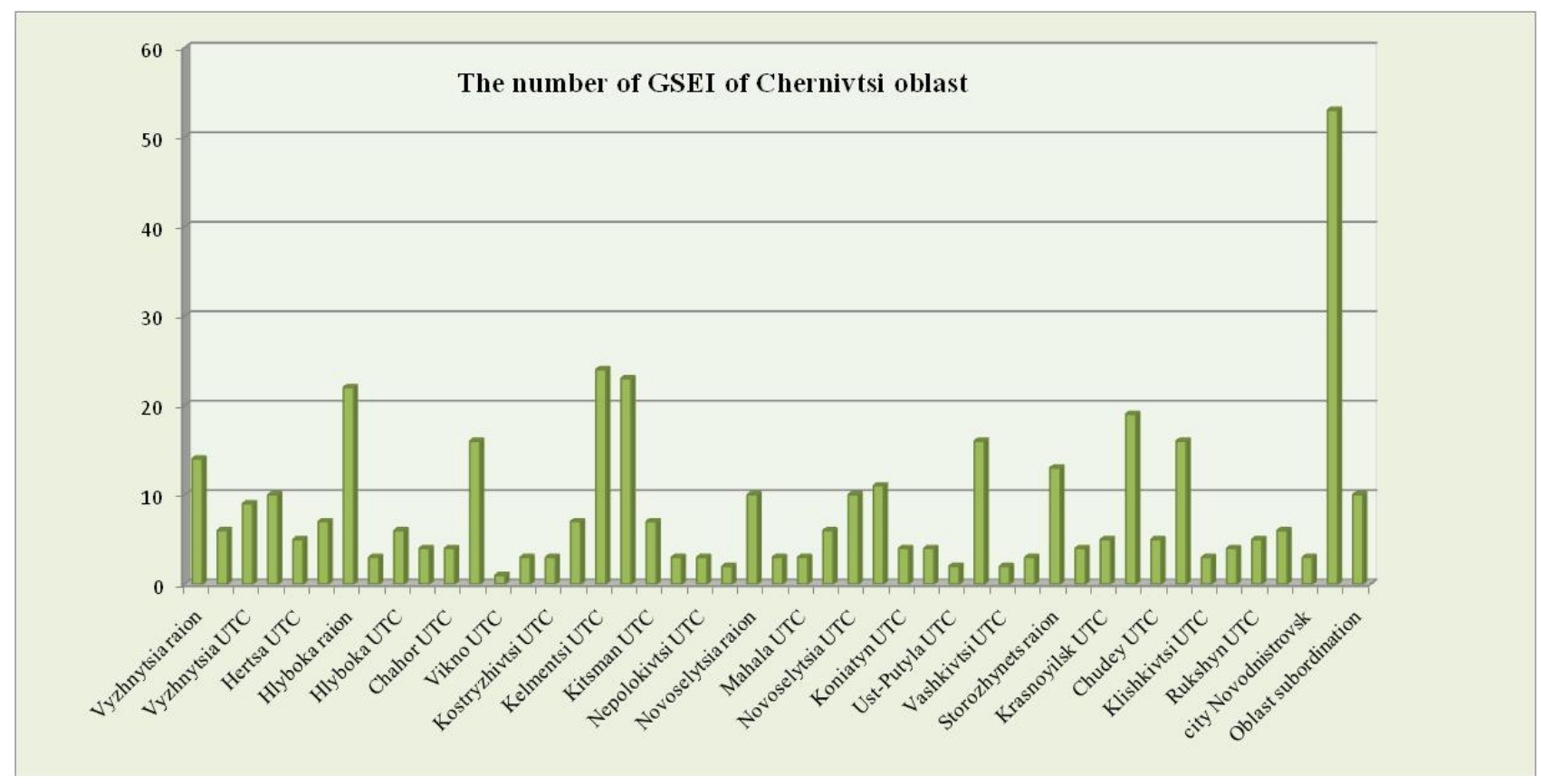

Fig. 1. The number of GSEI of Chernivtsi oblast

An important aspect of educational reform is the creation of educational districts. An educational district is a set of educational institutions, regardless of the type and form of ownership, which unite to achieve the next goal of providing quality educational services and ensuring free and equal access to them. The founders of the educational district may be representative bodies of local self-government of the united territorial communities and district councils. Within the administrative-territorial units, one or several educational districts can be created. Educational districts can also be created within several administrative-territorial units [9].

One of the elements of creating an educational dis- trict is the establishment of basic institutions and their branches. As of the beginning of the 2019-2020 school year, 14 basic educational institutions and 22 branches have been established in Chernivtsi oblast, in which children study in 421 classes. 7,354 students study in basic institutions and their branches [7].

Most basic institutions have been established in Hertsa raion ( 3 basic institutions and 6 branches), while in city Chernivtsi, Hlyboka and Putyla raions no basic educational institutions have been established (Fig. 2).

NVKs (6 institutions) and schools (5 institutions) predominate among the types of basic institutions. The institutions of the first level dominate among branches. 


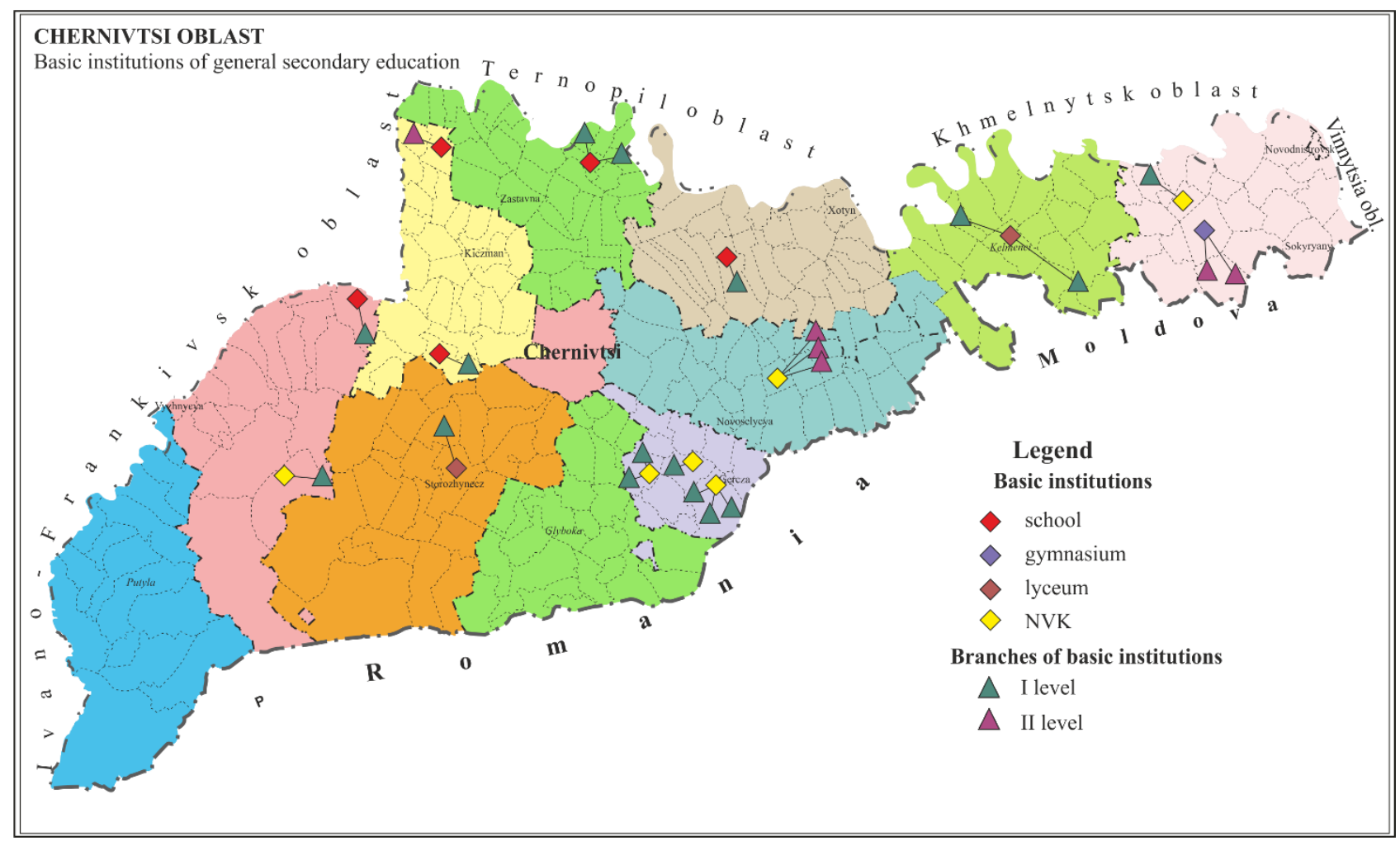

Fig. 2. Network of basic GSEIs of Chernivtsi oblast (as of April 1, 2020)

The establishment of basic institutions is one of the elements of optimizing the network of GSEI, as well as an important prerequisite for providing quality educational services. There are following conceptual approaches to improving the territorial organization of general secondary education institutions: cost approach (based only on economic indicators), the approach of "assessment of social significance" (quality of pedagogical potential, level of knowledge of students and others) and integrated socio-cost approach [8].

According to the regulations on the basic educational institution, the following requirements must be taken into account when establishing it [9]:

- educational needs of students in providing certain areas of specialization;

- ability to ensure the organization of preprofessional training and specialized training at the appropriate level;

- the level of provision of qualified teaching staff;

- availability of modern material and technical base;

- staffing of the library fund with textbooks, scientific-methodical, artistic and reference literature;

- availability and convenience of paved roads to ensure safe transportation of students and teachers to the place of study, work and residence.

In addition to the above, in our opinion, important factors for the establishment of a basic institution are the distance of transportation and the number of students who will need transportation, as well as the level of knowledge of students.

To plan and establish a basic institution, we propose to use the following factors:

- level of institution - the purpose of creating an educational district is to ensure equal access to quality education, as well as to create quality conditions for obtaining a complete general secondary education, that is why only institutions of III-rd level were studied for the establishment of a basic institution;

- location features - is an important factor, because it affects the daily routine of students and their well-being. With the help of GIS packages, the distance by road to schools from the most remote populated areas of the educational district was calculated;

- the number of students who will need transportation - when establishing a basic institution, it is possible to reduce the level in some branches, and accordingly it will be necessary to bring students from branches to the basic institution. The fewer students who will need transportation, the more cost-effective it is;

- area of student premises - when establishing a basic institution, the number of students in it will increase, that is why the total area of premises where students study is a very important factor;

- material and technical base - this assessment took into account the number of computers and computer classes, the presence of a gym, the presence of classrooms and workshops, as well as a built-in toilet, because these factors belong to the main in providing quality education;

- staffing of the library fund - the total number of textbooks, scientific and methodical, fiction and reference books;

- qualification of pedagogical staff - the number of teachers of the highest and first category was taken into account to characterize this factor;

- quality of knowledge of graduates - this factor characterizes the quality of educational services. It was determined on the basis of EIT, as the share of students scoring 160 or more points. 
To test the method of optimizing the network of GSEI we chose Kitsman raion of Chernivtsi oblast, which presents different types of settlements, there is a high number and density of population and there are demographically different settlements and certain socioeconomic disparities. Also, this district is optimal for the oblast and Ukraine in general, not only in terms of demographics, but also in terms of the size of the district, the peculiarities of the transport network, the number of GSEIs and students enrolled in them, as well as the fact that there are no schools with languages of national minorities, which need to take into account certain features when establishing basic institutions.

Currently, there are 37 general secondary education institutions in Kitsman raion (including 2 basic ones) with 7,698 students. According to the draft long-term plan for the establishment of UTC, 6 UTCs will be established in Kitsman raion. Most educational institutions are concentrated in Kitsman UTC (11) and Mamayivtsi UTC (9).

Given the fact that the founder of the basic district and basic institution can be a village, town, city council of the united territorial community, raion council, as well as taking into account the above factors, we propose the following ways to optimize the network of GSEIs of Kitsman raion:

- Nepolokivtsi village UTC - 1 educational district: Nepolokivtsi educational district. In this district there are 3 GSEIs of I-III levels. To create a basic institution, we propose to choose Nepolokivtsi GSEI of I-III levels, because it is the leader in most factors (location, number of students who will need transportation and staffing of the library fund), and in other factors the level of institutions is approximately the same. Orshivtsi GSEI and Revakivtsi GSEI of I-III levels - branches with the reduction to the II level.

- Stavchany village UTC - 1 educational district: Stavchany educational district. In this UTC there are 4 GSEIs, of which only one institution is of I-III levels (Stavchany GSEI) - it is efficient to establish on its basis a basic institution, and on the basis of other institutions branches, reducing Malyatyntsi GSEI to I-st level.

- Kyseliv village UTC - 1 educational district: Kyseliv educational district. At present, a basic institution (Kyseliv basic GEI of I-III levels) with one branch (Borivtsi GSEI) has already been established, as well as the existing Shyshkivtsi GSEI of I-III levels. After analyzing all the factors of formation of basic schools, we propose to create a branch of the existing basic institution from Shyshkivtsi GSEI, with its reduction to the II level.

- Brusnytsia village UTC. There are 8 GSEIs in UTC, of which three are institutions of I-III levels. The large area of the community, as well as the large distance of transportation of students to any of the GSEIs of I-III levels (more than $20 \mathrm{~km}$ ) leads to the creation of 2 educational districts: Brusnytsia (Brusnytsia village council) and Stanivtsi (Nyzhni Stanivtsi and Verkhni Stanivtsi village councils) educational districts. In Brusnytsia district there are 5 institutions of general secondary education, of which only one is of I-III levels (Brusnytsia GSEI of I-III levels), on the basis of which it is efficient to create a basic institution, as well as one institution of I-II levels and three institutions of I level, of which to create branches without changing levels.

- Kitsman city UTC. The largest community in the area, so, considering the distances between educational institutions, we propose to create 3 educational districts: Kitsman (Kitsman city council, Lashkivka, Valyava, Sukhoverkhiv, Davydivtsi and Klivodyn village councils), Oshykhliby (Oshykhliby and Ivankivtsi village councils), Shypyntsi (Shypyntsi village council) educational districts. In Kitsman district there are two institutions of I-III levels, one of II-III levels, four institutions of I-II levels and one institution of I level. Among the institutions of III level, Kitsman GSEI of IIII levels has a slight advantage (large area of educational premises, the best material and technical base), the second institution is Kitsman gymnasium, which has a significant advantage in the quality of graduates' knowledge. Also, these institutions have a convenient location, that is why we propose to create two basic institutions in this district - Kitsman GSEI (with branches Davydivtsi GSEI I - II 1., Sukhoverkhiv GSEI I - II 1., Klivodyn GSEI I - II 1., Valyava GSEI I - II 1., without the reduction in level) and Kitsman gymnasium (with branches Kitsman NVK and Lashkivka GSEI of IIII levels with reduction to the II level).

Since there are 2 GSEIs in Oshykhliby district, of which only one is an institution of I-III levels (Oshykhliby GSEI of I-III levels), on the basis of which it is efficient to create a basic institution with one branch (Ivankivtsi GSEI of I-II levels).

In the Shypyntsi district there is only one GSEI, but due to the considerable distance from other GSEIs (the distance to other GSEIs by paved roads is more than 20 $\mathrm{km}$ ), it is currently efficient to create a separate district without changes in the structure of educational institutions.

- Mamayivtsi village UTC. Given the area of the community $\left(154.8 \mathrm{~km}^{2}\right)$, as well as the presence of a natural barrier between settlements (the Prut River divides the community in half, and there is only one bridge), it is efficient to create 4 educational districts:

- Mamayivtsi (Mamayivtsi village council) - in this district there are 2 institutions of I-III levels. According to the absolute majority of factors, the leader is Mamayivtsi GSEI of I-III levels, on its basis is efficient to create a basic institution with a branch - Mamayivtsi NVK (with the reduction in level).

- Luzhany (Luzhany village council) - there is only one GSEI and V. Oreletskii Luzhany GSEI of I-III levels. Territorially, the creation of an educational district is possible only with the institutions of the Mamayivtsi district, but Mamayivtsi GSEI of I-III levels and V. Oreletskii Luzhany GSEI of I-III levels have a developed material and technical base, high-quality teaching staff, the same quality of students' knowledge, as well as a large number of students. That is why we propose to create a separate district without establishing a basic institution.

- Drachyntsi (Drachyntsi, Dubivtsi and Hlynnytsia village councils) - there are 4 GSEIs in the district: 1 basic, 1 branch, 2 institutions of I-II levels. Based on this, we propose to create branches of the already exist- 
ing Drachyntsi basic GSEI of I-III levels from Hlynnytsia GSEI of I-II levels and Dubivtsi GSEI of I-II levels, without changing their levels.

- Striletskyi-Kut (Striletskyi-Kut and Bila village councils) educational district. Its formation is due to the remoteness from other settlements of the community and due to the lack of roads caused by the Prut River. In this district there is one institution of I-III levels, which we propose to make basic, and two institutions of I levels are its branches.

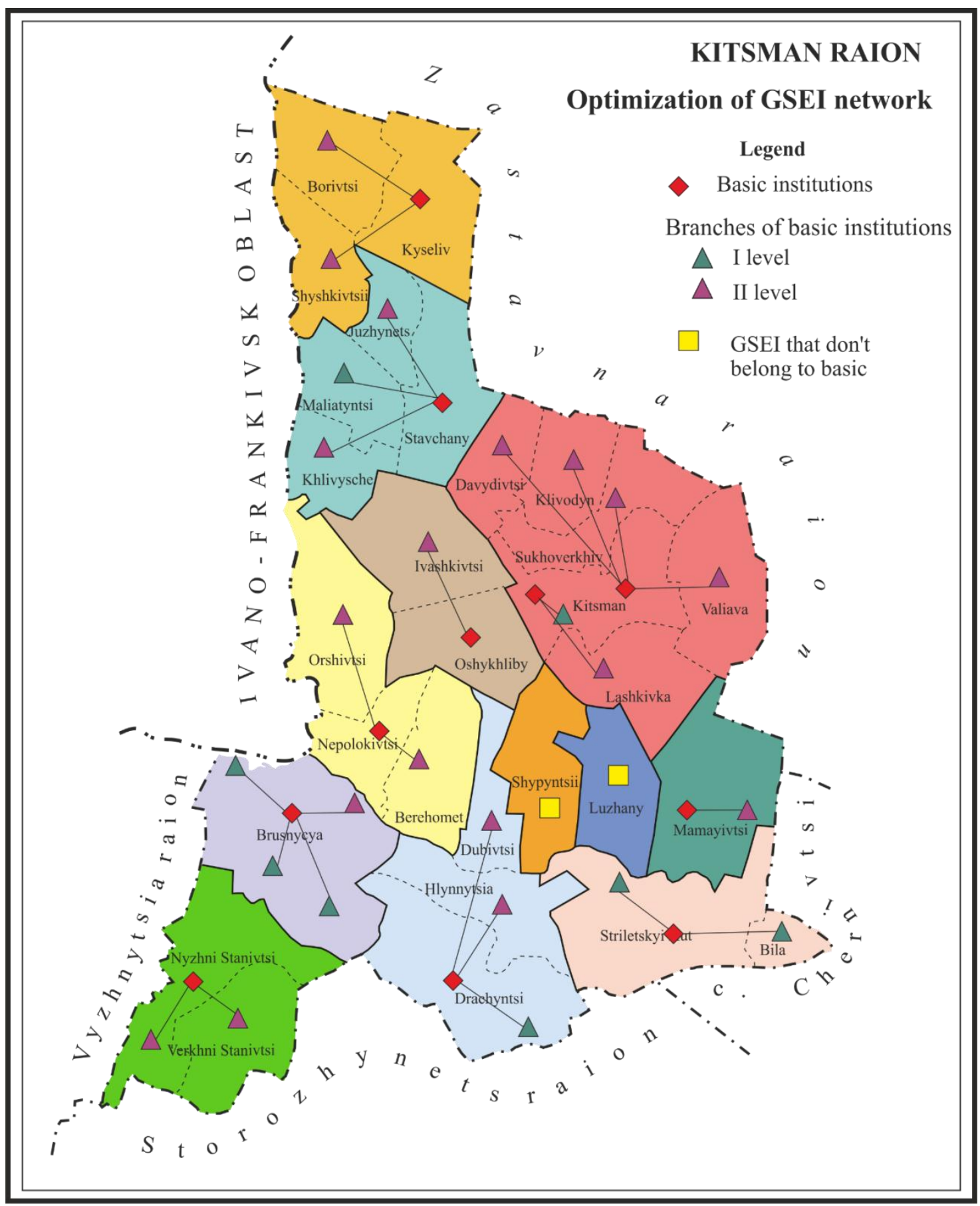

Fig. 3. Potential network of GSEIs of Kitsman raion of Chernivtsi oblast

In total, in Kitsman raion we propose to create 11 basic institutions and 26 branches, as well as to leave two GSEIs unchanged (Fig. 3). In most educational districts we propose to create one basic institution, only in Kitsman educational district - two, while in Shypyntsi and Luzhany educational districts, at the moment, not to create any basic institution, the main reason is their considerable distance from other educational institutions, which makes it impossible to transport students, because, according to sanitary norms, the distance to the school should not exceed 15 kilometers.

Conclusions of the study. Optimization of the network of general secondary education institutions is an important element on the way to quality educational services. Currently, 14 basic educational institutions and 22 branches have been established in Chernivtsi oblast.

When creating a basic institution, the state determines the following key factors: educational needs of 
students, ability to provide specialized training, the level of qualified teachers, material and technical base, staffing of the library fund and the availability and convenience of paved roads. In addition to these factors, we propose to take into account the location of institutions, because it will affect the distance and time of transportation of students, the number of students who will need transportation, and the level of knowledge of graduates, because this knowledge is an indicator of quality educational services.
After analyzing a number of factors of general secondary education institutions of Kitsman raion, we came to the conclusion that the network of GSEIs of the raion should be optimized by creating 11 basic institutions and 26 branches.

So, in our opinion, the defining characteristics that must be taken into account in the formation of basic institutions are the transport accessibility of educational institutions, material and technical base and the level of knowledge of graduates.

\section{References:}

1. Topuzov, O.M. (Eds.). (2018). Anotovani rezultaty naukovo-doslidnoi roboty Instytutu pedagogiky NAPN Ukrainy za 2018 rik [Annotated results of research work of the Institute of Pedagogy of the National Academy of Pedagogical Sciences of Ukraine for 2018]. Kyiv: Pedagogichna dumka [in Ukrainian].

2. Benovska, L.Ya. (2016). Formuvannya opornykh shkil v umovakh reformuvannya mistsevoho samovryaduvannya [Formation of support schools in the conditions of local self-government reform]. Sotsialno-ekonomichni problemy suchasnoho periodu Ukrainy, 2, 32-37 [in Ukrainian].

3. Virchenko, P. (2009). Osoblyvosti prostorovoi organizatsii struktury regionalnoi systemy osvity [Features of the spatial organization of the structure of the regional education system]. Chasopys sotsialno-ekonomichnoi geografii - Human Geography Journal, 7(2), 178-182 [in Ukrainian].

4. Zaiachuk, O.H. (2009). Terytorialna organizatsiya zahalnoosvitnikh zakladiv Chernivetskoi oblasti [Territorial organization of secondary schools of Chernivtsi region]. Naukovyi visnyk Volynskoho natsionalnoho universytetu im. Lesi Ukrainky. Seriya: Geografichni nauky, 116-120 [in Ukrainian].

5. Tsentr yakosti osvity (2020). Zvity i statystychni dani [Reports and statistics]. Retrieved from http://centr.cv.ua/?cat=7 [in Ukrainian].

6. Derzhavna kaznacheyska sluzhba Ukrainy (2020). Obyednani terytorialni hromady [United territorial communities]. Retrieved from https://www.treasury.gov.ua/ua/kaznachejstvo-informuye/obyednani-teritorialni-gromadi [in Ukrainian].

7. Ministerstvo osvity i nauky Ukrainy (2019). Oporni shkoly [Support schools]. Retrieved from https://mon.gov.ua/ua/osvita/zagalna-serednya-osvita/oporni-shkoli\ [in Ukrainian].

8. Pashkevych, M.S., \& Kharchenko, M.O. (2016). Naukovi zasady formuvannya merezhi opornykh shkil u regionakh Ukrainy [Scientificbases of formation of a network of basic schools in the regions of Ukraine]. Dnipropetrovsk: NHU [in Ukrainian].

9. Kabinet ministriv Ukrainy (2019). Postanova Pro zatverdzhennya Polozhennya pro osvitni okruh i opornyi zaklad osvity [Resolution on approval of the Regulations on the educational district and the basic educational institution]. Retrieved from https://www.kmu.gov.ua/npas/pro-zatverdzhennya-polozhennya-pro-osvitnij-okrug-i-opornijzaklad-osvit-m-190619 [in Ukrainian].

10. Ministerstvo okhorony zdorovya Ukrainy (2018). Sanitarnyi rehlament dlya zakladiv zahalnoi serednyoi osvity [Sanitary regulations for general secondary education institutions]. Retrieved from https://moz.gov.ua/uploads/1/6845-pro_20180828_1.pdf [in Ukrainian].

11. Stetskyi, V.V. (1998). Osvitniy kompleks Lvivskoi oblasti: sotsialno-ekonomiko-geografichni doslidzhennya [Educational complex of Lviv region: socio-economic-geographical research]. Lviv: LONMIO [in Ukrainian].

12. Flinta, N.I. (2005). Kulturno-osvitniy kompleks regionu i yoho terytorialna organizatsiya (na materialakh Ternopilskoi oblasti) [Cultural and educational complex of the region and its territorial organization (based on materials from Ternopil region)]. Kyiv [in Ukrainian].

Надійшла до редколегї 07.05.2020 p.

\section{Про автора:}

Юрій Білоус - аспірант кафедри географії України та регіоналістики, Чернівецький національний університет імені Юрія Федьковича, вул. М. Коцюбинського 2, корп. 4, м. Чернівці, 58012, Україна, bilous_jura@ukr.net, ORCID ID: 0000-0001-8539-275X

\section{Об авторе:}

Юрий Билоус - аспирант кафедры географии Украины и регионалистики, Черновицкий национальный университет имени Юрия Федьковича, ул. М. Коцюбинского, 2, корп. 4, г. Черновцы, 58012, Украина, bilous_jura@ukr.net, ORCID ID: 0000-0001-8539-275X 